\title{
Assessment of major requirements for accessing credit among paddy farmers in Jigawa state, Nigeria
}

\author{
Datti, M.I., ${ }^{*}$ Said, R., Ismail, N.W. and Abd. Rahman, A. \\ School of Business and Economics, Universiti Putra Malaysia 43400, UPM Serdang, Selangor, Malaysia
}

\section{Article history:}

Received: 9 July 2020

Received in revised form: 2 September 2020

Accepted: 31 October 2020

Available Online: 27

February 2021

\section{Keywords:}

Access to credit,

Financial institutions,

Paddy farming.

DOI:

https://doi.org/10.26656/fr.2017.5(2).339

\begin{abstract}
This paper examined major credit requirements of financial institutions in providing credit to paddy farmers of Jigawa state, Nigeria. Data were collected in 2019 from three selected paddy farming local government areas of the state. A total of 120 respondents were randomly selected through a multistage sampling technique, and a questionnaire. The binary logit model and the marginal effect were applied in the analysis. The results indicated that paddy farmers' educational level, family size, and guarantor requirements were statistically significant on access to credit, with their P-value signifies $0.041,0.060$, and 0.000 , respectively. While, farm size, administrative process, collateral requirement, interest charge, and principal repayment duration were insignificant on accessing credit. Failure to address these problems may continue to worsen the Nigerian government's effort on food self-sufficient and poverty alleviation. The study suggests similar research to consider more years to see the impact in the long term. The study further recommends credit providers to modify the guarantor requirement and to delegate a staff who can translate and guide the applicants on how to fill the credit application forms.
\end{abstract}

\section{Introduction}

Access to credit is vital in promoting crop processing, purchasing of farm equipment and inputs, technology adoption, among others. Many countries established microfinance institutions for providing financial services to farmers (Linh et al., 2019). The provision of credit to agribusiness entrepreneurs characterised by collateral, application procedures, and unfavourable interest rates among others (World Bank, 2013). However, It was reported about 1.7 billion households and adults from China, India, Bangladesh, Indonesia, Mexico, Pakistan, and Nigeria were unable to have sufficient access to financial institutions (World Bank, 2017). Farmers face problems of fulfilling the credit requirements from financial institutions. While inadequate infrastructure and irregular weather made financial institutions view agriculture as a high-risk business (Isaga, 2018). It was believed that any obstacle that prevents accessing funds will affect GDP, hamper national food security, and preclude the nation from achieving Sustainable Development Goals (Abraham, 2018). These problems affect the access to farm inputs such as fertilizer and will swell the rank of poverty (Abdullahi et al., 2016; Mustapha and Said, 2016). Nigeria established many financial institutions since the 1970s to provide credit to farmers. However, only $4 \%$ of total lending to the entire sectors was allocated to the agricultural sector by commercial banks. Meanwhile, there are numerous complaints from paddy farmers on the inability to access credit in Nigeria (Gabriel, 2018). Jigawa is one of thirty-six states, located in the northwestern part of Nigeria with about twenty-seven local government areas. It has a total land area of approximately 22,410 square kilometers with an estimated population of 5,041,500. Subsistence farming and animal husbandry are the major occupations of the people. There is an increase in land cultivation for paddy farming from 70,000-100, 0000 hectares with the production of 9 tons per hectares annually. Recently, most paddy farmers in Jigawa state were unable to repay the credit collected from the banks (CSL Stockbrokers, 2020).

The growth of population, income, and urbanization have substantially increased the global demand for rice, particularly in sub-Sahara Africa (SSA). Nigeria is one of the countries that produce and consume rice. It plays a significant role in food security and poverty reductions (FAO, 2020). Table 1 indicates Nigeria's domestic paddy production continues to increase annually since 2008, although, it has decreased from 3423 MT in 2012 
to $3038 \mathrm{MT}$ in 2013. However, the increase in the annual rate of consumption is more than production. It was forecasted that Nigeria's rice demand will continue growing to almost 36 million tons MT by 2050 (Adeyemo, 2018). The low production of paddy in Nigeria is connected to the failure of paddy farmers in various states like Jigawa to access credit from financial institutions.

Table 1. Nigeria's domestic rice production, consumption, and importation 2008-2017

\begin{tabular}{cccc}
\hline Year & $\begin{array}{c}\text { Domestic Production } \\
(000) \text { MT }\end{array}$ & $\begin{array}{c}\text { Consumption } \\
(000) \text { MT }\end{array}$ & $\begin{array}{c}\text { Area harvested } \\
\text { (hectare), 000 }\end{array}$ \\
\hline 2008 & 2632 & 4220 & 2382 \\
2009 & 2234 & 4350 & 1837 \\
2010 & 2818 & 4800 & 2433 \\
2011 & 2906 & 5600 & 2269 \\
2012 & 3423 & 5700 & 2864 \\
2013 & 3038 & 5800 & 2931 \\
2014 & 3782 & 6100 & 3082 \\
2015 & 3941 & 6400 & 3122 \\
2016 & 4410 & 6700 & 3170 \\
2017 & 4662 & 7100 & 3600 \\
\hline
\end{tabular}

Source: Index Mundi, 2019

Although, many studies established the significant effect of credit on improving farmers' production (Abraham, 2018; Makate et al., 2019). However, only a few studies analysed farmers' access to credit (Saqib et al., 2018; Ali and Awade, 2019). Therefore, this study assessed the effect of major credit requirements from financial institutions on accessing credit among paddy farmers in Jigawa State, Nigeria. This study is vital in providing information on the major obstacles that hinder paddy farmers from accessing credit.

\section{Materials and methods}

\subsection{Data source}

This study was based on primary data obtained from paddy farmers in Kaugama, Auyo and Ringim areas of Jigawa state, Nigeria around July- September 2019 through a questionnaire. The instrument consists of information on paddy farmers' demographic profile, farm inputs, and credit requirements. Moreover, the descriptive statistics were analysed.

\subsection{Sampling and sample size technique}

The multistage sampling technique was used in selecting the sample. It was designed when the elements of the population are spread over a wide geographical region. The paddy farmers of this study were scattered into various villages. The first stage was the selection of paddy producing villages. In the second stage, three villages namely Kaugama, Auyo, and Ringim areas were randomly selected from 11 paddy producing villages. In the third stage, the list of paddy farmers was obtained from respective village heads and extension personnel and stratified according to their farm size category. Finally, a total of 120 respondents were selected as a sample size.

\subsection{Analytical model}

The Binary logit model was selected because it is homoscedastic and the probabilities of dependent variables such as access to credit are dichotomous, which is 1 if access and 0 if not access. it can also permit multiple explanatory variables to be analysed simultaneously. The marginal effect of each independent variable was provided to prove the relationship with access to credit. Thus, the model specification was given as follows (Babcock et al., 1995).

$$
\begin{aligned}
& \operatorname{Prob}\left(Y_{i}=j\right)=\frac{e^{n j x i}}{1+e^{n j x i}} \\
& \mathrm{~J}=0 \text { or } 1, \text { then, } n_{0} \text { is assumed zero. } e^{n j x i}=1, \\
& \operatorname{Prob}\left(Y_{i}=j\right)=\frac{e^{n j x i}}{1+n^{2} e^{n k j x i}}
\end{aligned}
$$

Then, the probability of accessing credit $(\mathrm{j}=0$ or 1$)$

$$
\begin{aligned}
& \operatorname{Prob}\left(Y_{i}=0\right)=\frac{1}{1+\sum_{k=1}^{2} e \beta k X_{i}} \\
& \operatorname{Prob}\left(Y_{i}=1\right)=\frac{e \beta 1 X i}{1+\sum_{k=1}^{2} e \beta k X_{i}}
\end{aligned}
$$

Thus, the multinomial logistic model was expressed as follows:

$$
\operatorname{ProbY}_{i j}^{*}=\propto+\sum \beta_{k} X_{k}+\varepsilon_{Y_{i j}^{k}}
$$

Thus, access to credit was modelled as a function of demographic, farm factors, and credit requirements. Thus, for demographic factor, farm factor and administrative process were shown as follows:

$$
y_{i j}^{*}=\alpha_{0}+\Sigma_{j=1}^{1} \beta_{j} D M R_{i}+\Sigma_{j=1}^{2} \rho_{j} F R M_{i}+\Sigma_{j=1}^{3} \rho_{j} A D M_{i}+\varepsilon_{i}
$$

Where $y_{i j}^{*}=$ access to credit, $(1=$ Yes, $0=$ No $), \beta$ is a vector of parameters that relate the independent variables to the dependent variable. DMR signifies demographic profile which includes age, gender, level of education, family size, and income. Then FRM indicates farm factors that consist, farm size and farming experience (years). While ADM indicates major administrative requirements that paddy farmer is expected to fulfil before accessing credit from financial institutions. These are administrative processes include filling the application forms and processing for approval, guarantor requirement, collateral requirement, interest rate, and duration of principal repayment and $\varepsilon_{i}$ shows error terms. 


\section{Results and discussion}

This section is divided into two parts. The first part explains the socio-demographic characteristics of paddy farmers. The second part presents the results of the binary regression model and marginal effect, followed by a discussion of the significant effects and implications of variables on paddy production.

\subsection{Socio-demographic characteristics of paddy farmers}

Table 2. Socio-demographic characteristics of paddy farmers

\begin{tabular}{lcc}
\hline Variable & Frequency & Percentage \\
\hline Gender of the household head & & \\
\hline Male & 110 & 91.7 \\
Female & 10 & 8.3 \\
Age distribution & $37^{*}$ & \\
$18-35$ & 63 & 52.5 \\
$36-60$ & 51 & 42.0 \\
61 and above & 6 & 5.0 \\
\hline
\end{tabular}

Farming experience (years)

\begin{tabular}{lcc}
\hline $1-5$ & 17 & 14.2 \\
$6-10$ & 51 & 42.5 \\
$11-15$ & 36 & 30.0 \\
$16-20$ & 9 & 7.5 \\
21 above & 7 & 5.8 \\
\hline
\end{tabular}

Level of Education

\begin{tabular}{lll}
\hline No formal education & 13 & 10.8 \\
Primary school & 35 & 29.2 \\
Secondary school & 41 & 34.2 \\
Sub degree & 19 & 15.8 \\
Graduate & 12 & 10.0 \\
\hline
\end{tabular}

Family size (number)

\begin{tabular}{lcc}
\hline $1-5$ & 34 & 28.3 \\
$6-10$ & 56 & 46.7 \\
$11-15$ & 25 & 20.8 \\
$16-20$ & 3 & 2.5 \\
21 above & 2 & 1.7 \\
\hline
\end{tabular}

Yearly farming income status (naira) $139,0088^{*}$

\begin{tabular}{lcc}
\hline Low income & 90 & 75.0 \\
Middle income & 27 & 22.5 \\
High income & 3 & 2.5 \\
Farm size (hectares) & & \\
$0.1-2.0$ & 74 & 61.7 \\
$2.1-4.0$ & 37 & 30.8 \\
4.1 above & 9 & 7.5 \\
\hline
\end{tabular}

Quantity of paddy produced per $9793 \mathrm{kg*}$

hectares $(\mathrm{kg})$

\begin{tabular}{lcc}
\hline $1501-10000$ & 70 & 58.3 \\
$10001-18500$ & 40 & 33.3 \\
$18501-27000$ & 9 & 7.5 \\
$27001-45000$ & 1 & 8.3 \\
\hline
\end{tabular}

Credit

\begin{tabular}{lll}
\hline Accessed & 66 & 55.0 \\
Not accessed & 54 & 45.0 \\
\hline
\end{tabular}

* Mean of variable

eISSN: 2550-2166
Table 2 presents the sociodemographic characteristics of paddy farmers' in Kaugama, Auyo, and Ringim areas of Jigawa state. Most of the paddy farmers (about 92\%) in the study area are male, while only $8.3 \%$ of the respondents are female. Also, about $52.5 \%$ of the respondents are within the age bracket of youth. The average age of the respondents is 37 years old, which shows, the farmers are still within economic productive labour force age. Also, about $42.5 \%$ have paddy farming experience of at least 6-10 years. This is associated with the increasing demand for domestic paddy due to price increase and the banning of imported rice. Furthermore, the educational level of about $34.2 \%$ of respondents is a secondary certificate, while about $29.2 \%$ attended only primary school. It has been found that only $10 \%$ of the respondents are graduates. This shows there is low educational qualification among paddy farmers. The size of the farm is averagely within the small size category as only two hectares per farmer. This small size of land contributes to low output as average production was about $9793 \mathrm{Kg}$ per each farmer.

Binary logit regression and marginal effect results of each model were presented in Table 3. The first column of each model signifies $\mathrm{P}$ values of Binary logit result, while the figures inside the bracket, under $P$ values, and signifies the standard error coefficient of each variable. The first figure in the second column (ME) indicates the P-value of marginal effect. While the figure inside the bracket indicates the change that exists in accessing credit because of a variable. Thus, the Variance Inflation Factor (VIF) results were all below 5 value. Nevertheless, models VI involve summation regressions of all variables, demographic, farm factors, and administrative requirements.

Concerning demographic factors, the level of education is significant at $10 \%$ and $5 \%$ in model I-V and model VI, respectively. The significance of the educational level (0.041) in model VI shows that an increase in paddy farmers' level of education by $5 \%$ will lead to an increase of farmers' access to credit by $29 \%$. This shows the farmers with a good qualification tend to understand the documentation and administrative procedures of credit applications better and provide higher chances of getting guarantor and collateral requirements. Hence, this finding is on the same line as the results of some studies (Yunus et al., 2014; Yunus et al., 2015; Yunus and Said, 2016; Saqib et al., 2018). Moreover, family size is statistically significant in all models at $5 \%$. This is associated with the culture of early marriage and uncontrolled birthrate. Financial institutions were suspected the credit receives may be channeled towards family expenses and social status. While age, gender, and income were statistically 
Table 3. Effect of demographic factor, farm factor, and administrative requirements on access to credit

\begin{tabular}{|c|c|c|c|c|c|c|c|c|c|}
\hline \multirow{2}{*}{ Demographic } & \multicolumn{3}{|c|}{ MODEL I } & \multicolumn{3}{|c|}{ MODEL II } & \multicolumn{3}{|c|}{ MODEL III } \\
\hline & \multicolumn{2}{|c|}{$\mathrm{ME}$} & Robust & \multicolumn{2}{|c|}{$\mathrm{ME}$} & Robust & \multicolumn{2}{|c|}{$\mathrm{ME}$} & Robust \\
\hline Age & $\begin{array}{c}0.238 \\
(0.051)\end{array}$ & $\begin{array}{c}0.185 \\
(0.014)\end{array}$ & 0.195 & $\begin{array}{c}0.690 \\
(0.055)\end{array}$ & $\begin{array}{c}0.671 \\
(-0.004)\end{array}$ & 0.671 & $\begin{array}{c}0.387 \\
(0.487)\end{array}$ & $\begin{array}{c}0.349 \\
(-0.009)\end{array}$ & 0.355 \\
\hline Gender & $\begin{array}{c}0.256 \\
(0.684)\end{array}$ & $\begin{array}{c}0.214 \\
(-0.174)\end{array}$ & 0.223 & $\begin{array}{c}0.202 \\
(0.793)\end{array}$ & $\begin{array}{c}0.163 \\
(0.018)\end{array}$ & 0.178 & $\begin{array}{c}0.311 \\
(0.677)\end{array}$ & $\begin{array}{c}0.278 \\
(-0.157)\end{array}$ & 0.286 \\
\hline Level of education & $\begin{array}{c}0.092 * \\
(0.188)\end{array}$ & $\begin{array}{c}0.080^{*} \\
(0.071)\end{array}$ & $0.086^{*}$ & $\begin{array}{c}0.081^{*} \\
(0.197)\end{array}$ & $\begin{array}{c}0.067^{*} \\
(0.061)\end{array}$ & $0.081 *$ & $\begin{array}{c}0.096^{*} \\
(0.188)\end{array}$ & $\begin{array}{c}0.084 * \\
(0.071)\end{array}$ & 0.100 \\
\hline Family size & $\begin{array}{c}0.039 * * \\
(0.298)\end{array}$ & $\begin{array}{c}0.026^{* *} \\
(0.139)\end{array}$ & $0.038 * *$ & $\begin{array}{l}0.037 * * \\
(0.274)\end{array}$ & $\begin{array}{l}0.024 * * \\
(0.112)\end{array}$ & $0.036 * *$ & $\begin{array}{l}0.060 * \\
(0.294)\end{array}$ & $\begin{array}{c}0.044 * * \\
(0.127)\end{array}$ & $0.056^{* *}$ \\
\hline Income & $\begin{array}{c}0.874 \\
(5.250) \\
\end{array}$ & $\begin{array}{c}0.881 \\
(-1.880) \\
\end{array}$ & 0.881 & $\begin{array}{c}0.813 \\
(5.730) \\
\end{array}$ & $\begin{array}{c}0.823 \\
(-2.460) \\
\end{array}$ & 0.823 & $\begin{array}{r}0.903 \\
(5.210) \\
\end{array}$ & $\begin{array}{c}0.910 \\
(-1.450) \\
\end{array}$ & 0.910 \\
\hline \multicolumn{10}{|l|}{ Farm factors } \\
\hline Farm size & $\begin{array}{c}0.306 \\
(0.221)\end{array}$ & $\begin{array}{c}0.332 \\
(-0.051)\end{array}$ & 0.332 & $\begin{array}{c}0.543 \\
(0.245)\end{array}$ & $\begin{array}{c}0.534 \\
(-0.273)\end{array}$ & 0.536 & $\begin{array}{c}0.390 \\
(0.218)\end{array}$ & $\begin{array}{c}0.404 \\
(-0.428)\end{array}$ & 0.411 \\
\hline $\begin{array}{l}\text { Farming experience } \\
\text { (years) }\end{array}$ & $\begin{array}{r}0.580 \\
(0.239) \\
\end{array}$ & $\begin{array}{r}0.579 \\
(0.029) \\
\end{array}$ & 0.580 & $\begin{array}{c}0.543 \\
(0.247) \\
\end{array}$ & $\begin{array}{c}0.892 \\
(0.006) \\
\end{array}$ & 0.892 & $\begin{array}{l}0.060^{*} \\
(0.196)\end{array}$ & $\begin{array}{l}0.035^{* *} \\
(0.127)\end{array}$ & $0.048 * *$ \\
\hline \multicolumn{10}{|c|}{ Administrative requirement } \\
\hline Admin process & $\begin{array}{c}0.213 \\
(0.501)\end{array}$ & $\begin{array}{c}0.175 \\
(-0.141)\end{array}$ & 0.185 & & & & & & \\
\hline $\begin{array}{l}\text { Guarantor } \\
\text { requirement }\end{array}$ & & & & $\begin{array}{c}0.000 * * * \\
(0.478)\end{array}$ & $\begin{array}{c}0.000 * * * \\
(0.397)\end{array}$ & $0.000 * * *$ & & & \\
\hline $\begin{array}{l}\text { Collateral } \\
\text { requirement }\end{array}$ & & & & & & & $\begin{array}{r}0.840 \\
(0.425) \\
\end{array}$ & $\begin{array}{c}0.837 \\
(0.019)\end{array}$ & 0.837 \\
\hline Pseudo $\mathrm{R}^{2}$ & $0.0678^{*}$ & & & 0.209 & & & $0.05^{* *}$ & & \\
\hline Probability chi ${ }^{2}$ & 0.1907 & & & $0.000 * * *$ & & & 0.290 & & \\
\hline
\end{tabular}

\begin{tabular}{|c|c|c|c|c|c|c|c|c|c|}
\hline \multirow{3}{*}{$\begin{array}{l}\text { Demographic } \\
\text { Age }\end{array}$} & \multicolumn{3}{|c|}{ MODEL IV } & \multicolumn{3}{|c|}{ MODEL V } & \multicolumn{3}{|c|}{ MODEL VI } \\
\hline & \multicolumn{2}{|c|}{ ME } & \multirow{2}{*}{$\begin{array}{c}\text { Robust } \\
0.370\end{array}$} & \multicolumn{2}{|c|}{ ME } & \multirow{2}{*}{$\begin{array}{c}\text { Robust } \\
0.425\end{array}$} & \multicolumn{2}{|c|}{ ME } & \multirow{2}{*}{$\begin{array}{c}\text { Robust } \\
0.546\end{array}$} \\
\hline & $\begin{array}{c}0.402 \\
(0.049)\end{array}$ & $\begin{array}{c}0.364 \\
(-0.009)\end{array}$ & & $\begin{array}{c}0.459 \\
(0.049)\end{array}$ & $\begin{array}{c}0.422 \\
(-0.008)\end{array}$ & & $\begin{array}{c}0.581 \\
(0.061)\end{array}$ & $\begin{array}{c}0.546 \\
(0.006)\end{array}$ & \\
\hline Gender & $\begin{array}{c}0.300 \\
(0.678) \\
\end{array}$ & $\begin{array}{c}0.261 \\
(-0.160) \\
\end{array}$ & 0.269 & $\begin{array}{c}0.228 \\
(0.689) \\
\end{array}$ & $\begin{array}{c}0.186 \\
(-0.184) \\
\end{array}$ & 0.200 & $\begin{array}{c}0.207 \\
(0.828) \\
\end{array}$ & $\begin{array}{c}0.158 \\
(0.179) \\
\end{array}$ & 0.170 \\
\hline Level of education & $\begin{array}{l}0.091^{*} \\
(0.188) \\
\end{array}$ & $\begin{array}{l}0.079^{*} \\
(0.073) \\
\end{array}$ & $0.095^{*}$ & $\begin{array}{l}0.069^{*} \\
(0.190) \\
\end{array}$ & $\begin{array}{l}0.060^{*} \\
(0.077) \\
\end{array}$ & $0.080^{*}$ & $\begin{array}{l}0.041^{* *} \\
(0.837) \\
\end{array}$ & $\begin{array}{c}0.044^{* *} \\
(0.289) \\
\end{array}$ & 0.059 \\
\hline Family size & $\begin{array}{l}0.05^{* *} \\
(0.294)\end{array}$ & $\begin{array}{l}0.036^{* *} \\
(0.131)\end{array}$ & $0.048^{* *}$ & $\begin{array}{l}0.045^{* *} \\
(0.295)\end{array}$ & $\begin{array}{l}0.035^{* *} \\
(0.131)\end{array}$ & 0.490 & $\begin{array}{l}0.060 * * \\
(0.356)\end{array}$ & $\begin{array}{l}0.060^{* *} \\
(0.115)\end{array}$ & 0.076 \\
\hline Income & $\begin{array}{c}0.903 \\
(5.220) \\
\end{array}$ & $\begin{array}{c}0.910 \\
(-1.450) \\
\end{array}$ & 0.910 & $\begin{array}{c}0.851 \\
(5.340) \\
\end{array}$ & $\begin{array}{c}0.862 \\
(-2.220) \\
\end{array}$ & 0.862 & $\begin{array}{c}0.949 \\
(5.790) \\
\end{array}$ & $\begin{array}{c}0.953 \\
(6.310) \\
\end{array}$ & 0.935 \\
\hline \multicolumn{10}{|l|}{ Farm factors } \\
\hline Farm size & $\begin{array}{c}0.349 \\
(0.221)\end{array}$ & $\begin{array}{c}0.374 \\
(0.047)\end{array}$ & 0.383 & $\begin{array}{c}0.352 \\
(0.223)\end{array}$ & $\begin{array}{c}0.353 \\
(-0.456)\end{array}$ & 0.363 & $\begin{array}{c}0.574 \\
(0.601)\end{array}$ & $\begin{array}{c}0.505 \\
(0.580)\end{array}$ & 0.506 \\
\hline $\begin{array}{l}\begin{array}{l}\text { Farming experience } \\
\text { (years) }\end{array} \\
\end{array}$ & $\begin{array}{c}0.635 \\
(0.187) \\
\end{array}$ & $\begin{array}{c}0.629 \\
(0.259) \\
\end{array}$ & 0.629 & $\begin{array}{l}0.092^{*} \\
(0.195) \\
\end{array}$ & $\begin{array}{l}0.062^{*} \\
(0.076) \\
\end{array}$ & $0.075^{*}$ & $\begin{array}{c}0.855 \\
(0.285) \\
\end{array}$ & $\begin{array}{c}0.843 \\
(0.009) \\
\end{array}$ & 0.848 \\
\hline \multicolumn{10}{|c|}{ Administrative requirements } \\
\hline Admin process & & & & & & & $\begin{array}{c}0.469 \\
(0.643) \\
\end{array}$ & $\begin{array}{c}0.462 \\
(0.799) \\
\end{array}$ & 0.462 \\
\hline $\begin{array}{l}\text { Guarantor } \\
\text { requirement }\end{array}$ & & & & & & & $\begin{array}{c}0.000^{* * * *} \\
(0.868)\end{array}$ & $\begin{array}{c}0.000^{* * * *} \\
(0.601)\end{array}$ & $0.000^{* * *}$ \\
\hline $\begin{array}{l}\text { Collateral } \\
\text { requirement }\end{array}$ & & & & & & & $\begin{array}{c}0.687 \\
(0.519)\end{array}$ & $\begin{array}{c}0.695 \\
(0.036) \\
\end{array}$ & 0.694 \\
\hline Interest rate & $\begin{array}{c}0.655 \\
(0.423) \\
\end{array}$ & $\begin{array}{c}0.669 \\
(-0.042) \\
\end{array}$ & 0.665 & & & & $\begin{array}{c}0.666 \\
(0.501)\end{array}$ & $\begin{array}{c}0.675 \\
(0.037) \\
\end{array}$ & 0.675 \\
\hline $\begin{array}{l}\text { Duration of principal } \\
\text { repayment }\end{array}$ & & & & $\begin{array}{l}0.071^{*} \\
(0.398)\end{array}$ & $\begin{array}{l}0.061^{*} \\
(0.159)\end{array}$ & $0.080^{*}$ & $\begin{array}{c}0.119 \\
(0.229) \\
\end{array}$ & $\begin{array}{c}0.104 \\
(0.061) \\
\end{array}$ & 0.116 \\
\hline $\begin{array}{l}\text { Pseudo } \mathrm{R}^{2} \\
\text { Probability chi }\end{array}$ & $\begin{array}{c}0.059^{*} \\
0.280\end{array}$ & & & $\begin{array}{c}0.078^{*} \\
0.114\end{array}$ & & & $\begin{array}{c}0.205 \\
0.000^{* * * *}\end{array}$ & & \\
\hline
\end{tabular}

ME, Marginal Effects. Significance levels $* \mathrm{p}<0.1, * * \mathrm{p}<0.05, * * * \mathrm{p}<0.01$ 
insignificant in all models. Moreover, farm factors that include farm size and farming experience (years) have shown upon all models designed in this study, farm size is statistically insignificant, while farming experience (years) is significant at $10 \%$ in model III and V. For instance, in model III, an increase of farming experience (years) by $5 \%$, increased access to credit by $12.7 \%$. Also, in model $\mathrm{V}$, an increase of farming experience (years) by $5 \%$, may increase access to credit by $7.6 \%$. This is attributed to experience in the nature of financial institutions debt recovery and learning of procedures on how to apply for credit. Conversely, from model VI, the guarantor requirement is significant on access to credit in the study area at $1 \%$. Besides, an increase in $1 \%$ of the guarantor requirement can lead to $60 \%$ access to credit.

This result is similar to a statistically significant guarantor requirement in model II. It shows that an increase in $1 \%$ of guarantor requirements, may lead to an increase in credit access by $40 \%$. This positive impact of the guarantor requirement is associated with strong trust, risk-taker from the financial institutions which save the organisation from bad debt. The credit received can be assured to be paid the receiver or by the surety. This statistical finding is also the same as the finding of Assogba et al., (2017). While, administrative process, collateral requirement, interest charge, and duration of principal repayment were insignificant in accessing credit in the study area. These may be related to high returns of harvested crops, low-interest charges, and support from both state and federal government. Also, the collateral requirement does not affect the farmer's credit application. This is because the financial institutions in collaboration with traditional authority authenticate the validity of the land documents before accepting as a collateral requirement. Moreover, farmers do not bother about the period to repay the principal. The findings of insignificant interest rate, collateral, and duration of repayment principal were contrary to the results of Khanal and Regmi, (2017) and Saqib et al., (2018).

\section{Conclusion}

The study found the guarantor requirement was positively significant in accessing credit from financial institutions in the study area. The inability of many paddy farmers to access credit contributes to paddy farming to remains subsistence in the study area. The situation may worsen the Nigerian government's efforts on food self-sufficient and poverty alleviation. The study recommends to credit providers to modify the guarantor requirement and to delegate a staff who can translate and guide the applicants on how to fill the credit application form. The government can use this study as a challenge to the adult education programme side. Future studies are to be conducted on the data to see the impact in the long term.

\section{Conflict of interest}

The authors declare no conflict of interest.

\section{References}

Abdullahi, I., Noor, Z.M., Said, R. and Baharumshah, A.Z. (2016). Does poverty influence prevalence of child labor in developing countries? International Journal of Economics and Financial Issues, 6(1),712.

Abraham, T.W. (2018). Estimating the effects of financial access on poor farmers in rural northern Nigeria. Financial Innovation, 4(25), 1-20. https:// doi.org/10.1186/s40854-018-0112-2

Adeyemo, I. (2018, April 12). Nigeria's population now 198 million - NPC. 6-7. Retreived from Premium Times website: https://www.premiumtimesng.com/ news/top-news/264781-nigerias-population-now-198 -million-npc.htm

Ali, E. and Awade, N.E. (2019). Credit constraints and soybean farmers' welfare in subsistence agriculture in Togo. Heliyon, 5(4), 1-24. https:// doi.org/10.1016/j.heliyon.2019.e01550

Assogba, P.N., Kokoye, S.E.H., Yegbemey, R.N., Djenontin, J.A., Tassou, Z., Pardoe, J. and Yabi, J.A. (2017). Determinants of credit access by smallholder farmers in North-East Benin. Journal of Development and Agricultural Economics, 9(8), 210 -216. https://doi.org/10.5897/JDAE2017.0814

Babcock, B.A., Chaherli, N.M. and Lakshminara-yan, P. (1995). Programme Participation and Farm-Level Adoption of Conservation Tillage: Estimates from a Multinomial Logit Model. Retrieved from Iowa State University: card_workingpapers/145/

CSL stockbrokers. (2020). Hurdles before CBN, as ABP beneficiaries fail to repay loan. Retrieved from Nairametrics website: https:// nairametrics.com/2020/02/04/hurdles-before-cbn-asabp-beneficiaries-fail-to-repay-loan/

FAO. (2020). Nigeria at a glance. Retrieved from FAO website: http://www.fao.org/nigeria/fao-in-nigeria/ nigeria-at-a-glance/en/

Gabriel, E. (2018). Access To Financing Agriculture. Nigeria: Leadership Nigeria Newspaper.

Index Mundi. (2019). Nigeria Milled Rice Production by Year. Adapted from the United State Department of Agriculture. Retrieved on August 3, 2019, from 
website: https://www.indexmundi.com/agriculture/? country $=$ ng\&commodity $=$ milledrice \&graph $=$ production

Isaga, N. (2018). Access to bank credit by smallholder farmers in Tanzania: a case study. Afrika Focus, 31, 241-256. https://doi.org/10.21825/af.v31i1.9048

Khanal, A.R. and Regmi, M. (2017). Financial constraints and production efficiency: A case from rice growers in drought-prone areas of Indonesia. Agricultural Finance Review, 78, 25-40. https:// doi.org/10.1108/AFR-07-2016-0068

Linh, T.N., Long, H.T., Chi, L.Van, Tam, L.T. and Lebailly, P. (2019). Access to rural credit markets in developing countries, the case of Vietnam: A literature review. Sustainability (Switzerland), 11(5), 1-18. https://doi.org/10.3390/su11051468

Makate, C., Makate, M., Mutenje, M., Mango, N. and Siziba, S. (2019). Synergistic impacts of agricultural credit and extension on the adoption of climate-smart agricultural technologies in southern Africa. Environmental Development, 2019, 100458. https:// doi.org/10.1016/j.envdev.2019.100458

Mitra, S. and Prodhan, M.H. (2018). Factors determining credit access of tomato farmers in a selected area of Bangladesh. National Journal of Multidisciplinary Research and Development, 3(1), 406-410.

Mustapha, A.B. and Said, R. (2016). Factors influencing fertilizer demand in developing countries: evidence from Malawi. Journal of Agribusiness in Developing and Emerging Economies, 6(1), 59-71. https:// doi.org/10.1108/JADEE-10-2013-0040

Saqib, S.E., Kuwornu, J.K.M., Ahmad, M.M. and Panezai, S. (2018). Subsistence farmers' access to agricultural credit and its adequacy some empirical evidences from Pakistan. International Journal of Social Economics, 45(4), 644-660. https:// doi.org/10.1108/IJSE-12-2016-0347

Demirgüç-Kunt, A., Klapper, K., Singer, D., Ansar, A. and Hess, J. (Eds.) (2018). Global Findex Database 2017: Measuring Financial Inclusion and the Fintech Revolution. Washington DC: World Bank. https:// doi.org/10.1596/978-1-4648-1259-0

World Bank. (2013). Growing Africa: Unlocking the Potential of Agribusiness. Retrieved from The World Bank website: http://siteresources.worldbank.org/ INTAFRICA/Resources/africa-agribusiness-report2013.pdf

Yunus, N.M and Said, R. (2016). Do higher levels of qualification lead to higher returns to education: Evidence from the Malaysian education sector. International Journal of Economics and Financial Issues, 6(6Special Issue), 20-26.
Yunus, N.M., Said, R. and Hook, L.S. (2014). Do cost of training, education level and R\&D investment matter towards influencing labour Productivity? Jurnal Ekonomi Malaysia, 48(1), 133-142. https:// doi.org/10.17576/JEM-2014-4801-11

Yunus, Norhanishah Mohamad, Said, R. and AzmanSaini, W.N.W. (2015). Spillover effects of FDI and trade on demand for skilled labour in Malaysian manufacturing industries. Asian Academy of Management Journal, 20(2), 1-27. 